Pregledni znanstveni rad

DOI: $10.17234 /$ Croatica.42.16

UDK: [811.163.42’36:050]“18/19“"

Primljen: 3. II. 2018.

Prihvaćen: 23. II. 2018.

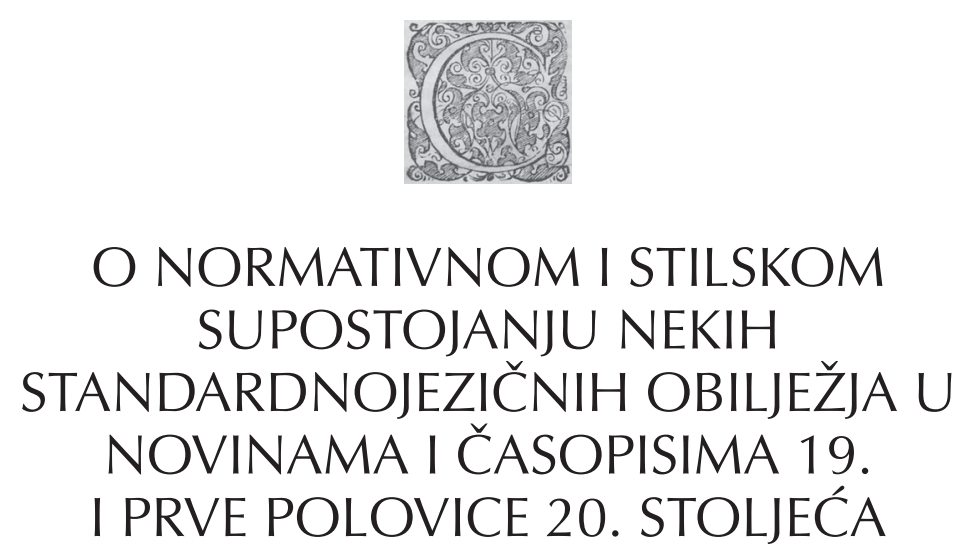

\title{
Vlasta Rišner
}

Filozofski fakultet Sveučilišta J. J. Strossmayera u Osijeku

Odsjek za hrvatski jezik i književnost

vrisner@ffos.hr

U tekstu se opisuju supostojanja dijela slovopisnih, morfoloških i sintaktičkih obilježja hrvatskih novina i časopisa iz 19. te dijela 20. stoljeća (do polovice četvrtoga desetljeća), osobito ostvaraja slogotvornoga $/ r /$, fonema $/ \dot{z} /$, odraza dugoga jata, staroštokavskih i novoštokavskih nastavaka dativa, lokativa i instrumentala množine te glagolskih priloga sadašnjih u atributnoj ulozi. Pokazuje se da veći dio novinsko-časopisne građe ne bilježi oštre normativne smjene ni na jednoj uspoređenoj razini. Osim normativnih inačica opisuju se i stilske, i to na sintaktičkoj razini. Analiziraju se primjeri raščlanjivanja jednočlanog glagolskog predikata na dvočlani predikat sastavljen od suznačnoga (u navedenim primjerima pomoćnog ili modalnog) glagola i imenice te složeni glagolski predikati s infinitivom uz pomoćni glagol biti u bezličnim rečenicama s modalnim značenjem.

Ključne riječi: novine i časopisi 19. i prve polovice 20. stoljeća, supostojanje, raščlanjivanje predikata, infinitiv, sintaktička sinonimija 


\section{UVOD}

Tijekom devetnaestoga i dvadesetog stoljeća u povijesti su hrvatskoga jezika bile česte smjene norma. Uzroci normativnih zahvata bili su nerijetko sociolingvistički, a među uzroke može se ubrojiti i postojanje inačica, osobito na slovopisnoj, pravopisnoj i morfološkoj te u nekim razdobljima i na leksičkoj razini. ${ }^{1}$ Međutim, inačice su bile ne samo uzrokom nego i posljedicom normativnih smjena. Ivo Pranjković, opisujući temeljna načela jezične pravilnosti, jednakovrijednost na kojoj od razina smatra nužnom posljedicom jezičnoga razvoja:

Riječ je obično o nužnom supostojanju staroga i novoga, općega i specijaliziranoga, "višega" i "nižega", stilski obilježenoga i stilski neobilježenoga itd. Varijantnost, između ostalog, pomaže da se naviknemo na novi oblik i tako promjenu norme čini manje bolnom. Inačice nam, osim toga, pomažu da efektnije i preciznije "preslikavamo" svoje misli u jezična ustrojstva (Pranjković 2010: 10).

U ovom se radu opisuju slovopisna, pravopisna, morfološka i sintaktička prepletanja starih i novih obilježja druge polovice 19. i prvih četrdesetak godina 20. stoljeća. Na slovopisnoj se razini izdvajaju slogotvorni /rol, ostvaraji fonema /ź/ te odraza dugoga jata kao pokazatelji promjena u različitim smjerovima, dok usporedba svih fonema čije se pisanje u navedenu vremenu mijenjalo prelazi okvire ovoga rada.

Rasprave o slovopisu i pravopisu u hrvatskim su tiskovinama bile česte, a u radu se izdvajaju riječi urednika "Kola", i to iz dvaju razloga: 1 - "Kolo" se smatra prvim hrvatskim časopisom, iako to službeno nikada nije bilo jer se za nj nije tražila carska povlastica kojom se odobravalo izdavanje periodičnih publikacija; 2 - "Kolo" je do sredine 19. stoljeća slijedilo normu Zagrebačke filološke škole, no nakon Bečkoga dogovora urednik Stanko Vraz mijenja jezik i slovopis te se na stranicama "Kola" može govoriti o normativnim supostojanjima, i to ne samo na slovopisnoj nego i na morfološkoj razini.

Od morfoloških se obilježja izdvajaju ona u kojima je supostojanje, a onda i smjena jednoga obilježja drugim, najvidljivije: s jedne su strane nesin-

\footnotetext{
I. Pranjković (2010: 10) kao osnovni razlog "zahvatima u bilo kojem standardnom jeziku" opisuje postojanje inačica "na svim razinama (fonološkoj, morfološkoj, tvorbenoj, sintaktičkoj, leksičkoj, ortografskoj i ortoepskoj)." Što se tiče "zahvata" na leksičkoj razini, može se reći da su povezani s društvenopolitičkim promjenama te je najviše takvih utjecaja na jezik bilo nakon 1918. i ujedinjenja u Kraljevstvo SHS (v. Samardžija 2012), kao i u vrijeme NDH (v. Samardžija 1993a, 1993b) te nakon Domovinskoga rata i osamostaljenja Republike Hrvatske.
} 
kretizirani nastavci dativa i lokativa množine sukladni normi Zagrebačke filološke škole, a s druge sinkretizirani novoštokavski nastavci spomenutih padeža. Uspoređuje se i uporaba glagolskih priloga sadašnjih u ulozi participa koja se u drugu polovicu 19, ali i u 20. stoljeće, prenosi iz ranijih razdoblja.

Složenost se odnosa istražuje u novinama i dijelu časopisa koji potvrđuju publicistički te, rubno, književnoumjetnički, administrativni i razgovorni stil. Ta se građa smatra najboljom potvrdom miješanja više jezičnih obilježja zbog različitosti sadržaja koji se nerijetko ostvaruje i različitim izrazom: tako službeni dopisi, tekstovi natječaja i oglasa donose više obezličenih rečenica, raščlanjenih predikata i sekundarnih prijedloga koji supostoje sa stilski neobilježenim jezičnim sredstvima. Oglasi čuvaju starija jezična obilježja jer se nepromijenjeni objavljuju u više godišta, a često unose i elemente razgovornoga stila. Iako je uspoređeno znatno više novina i časopisa, donose se primjeri iz nekolicine čije se kratice navode na kraju rada. Novinsku građu među ostalim čini u 19. stoljeću vrlo utjecajan "Pozor / Obzor", ${ }^{2}$ koji je često bivao zabranjivan i plijenjen te je zbog toga mijenjao ime i mjesto tiska. U radu se navode primjeri iz "Novog Pozora" (od 1867. do 1869. tiskan u Beču), "Zatočnika" (tiskan u Sisku nakon promjene imena i zabrane "Novog Pozora") te "Obzora". ${ }^{3}$ Među brojnijima su i primjeri iz "Jutarnjega lista", dok su najstarije potvrde iz "Narodnih novina", a najmlađu građu (iz 1932. i 1934. godine) donosi prvi hrvatski časopis za žene "Ženski list" čija je urednica bila Marija Jurić Zagorka. Među brojnijim su primjerima u radu oni iz časopisa "Dom i sviet" pouku i viesti o dnevnih dogodjajih, javnom $i$ družtvenom životu, umjetnosti i znanosti, trgovini i obrtu, glasbi, kazalištu i modi. Već morfonološki pravopis, slovopisna rješenja dugoga odraza jata i jezik (staroštokavski nastavci lokativa) toga podužega podnaslova upućuju na čuvanje starije norme: tek od 1919. dugi se odraz jata ondje bilježi s ije, 1920. uvedeno je slovo $d$, a staroštokavski nastavci u velikoj mjeri supostoje s novoštokavskima do 1907. godine, iako se primjeri starih nastavaka nalaze i kasnije.

2 O književnopovijesnom značenju Pozora/Obzora piše Antun Barac (1936) u Spomen knjizi $1860-1935$.

3 Na početku izlaženja, 1860, novine su nazvane "Pozor", a pod tim su imenom izlazile i od 1881. do 1885. godine. Kao "Obzor" tiskane su od 1871. do 1881. te od 1886. godine do travnja 1941. godine, kada se gase. Od 1905. godine postojala su dva izdanja, do 1920. "Jutarnji”, a do 1919. i "Popodnevni Obzor".

4 Dom i sviet (od 1919. Dom i svijet) izlazio je od 1888. do 1923. godine. 
Izdvojeni se različiti izrazi za jednak jezični sadržaj dijele u dvije veće skupine, ovisno o tome jesu li nastali kao rezultat normativnih promjena ili su rezultat unutarjezičnih mijena i ocrtavaju stilske razlike. Supostojanje je na slovopisnoj i morfološkoj razini povezano s normativnim promjenama, za razliku od sintaktičke sinonimije koja podrazumijeva stilsko supostojanje. U radu se među stilskim supostojanjima opisuju raščlanjeni dvočlani predikati sastavljeni od suznačnoga (u navedenim primjerima pomoćnog ili modalnog) glagola i imenice koji se upotrebljavaju uz jednočlane glagolske predikate, kao i obezličeni predikati u kojima su značenjski izjednačeni glagoli biti i trebati uz infinitiv.

\section{NORMA I INAČICE}

\subsection{Slovopisna i pravopisna razina}

U novinama i časopisima druge polovice 19. i prve polovice 20. stoljeća često se spominje pravopis, a opisuje slovopis. Tako je i u tekstu urednika “Kola” Mirka Bogovića koji 1853. godine govori da su Gundulićeve pjesme objavljene drukčije od ostaloga dijela "Kola" jer ih je on, Bogović, prilagodio $^{5}$ donedavnomu Matičinu pravopisu, a zapravo slovopisu:

Ja sam glede pravopisa slědio onaj pravac, kojega se je kod preštampavanja naših dubrovačkih klasikah dèržala sve do novie doba Matica naša. Uslěd toga dakle zabacio sam najprie pravopis rukopisa po pravilu talijanskom ustrojen, pa zatim u rěčih kao n. p. sèrce i lěpo stavio sam u mesto $\grave{e}-\grave{a}$, a u město $\check{e}-i e$; najme sarce i liepo (K 1853: 3. nepaginirana str.).

Bogović govori o bilježenju dugoga odraza jata i slogotvornog $/ r /$, fonemima koji se ostvaruju na više načina u kratkom razdoblju ne samo u "Kolu" nego i u ostalim hrvatskim novinama i časopisima 19. stoljeća. ${ }^{6}$

5 Gundulićevu pjesmu Suze i tužbe Radmilove Bogović i sadržajno mijenja dodajući joj stih za koji je procijenio da nedostaje. Promijenio je i dvije Gundulićeve riječi "radi sroka i boljeg smisla." (K 1853: 3. nepaginirana str.)

6 Vrlo su česte slovopisne promjene i na stranicama "Zore dalmatinske", u kojoj se uz početni dalmatinski slovopis, čija su obilježja i uporaba $x$ umjesto ilirskoga $\check{z}$, ç umjesto $c$ te dvoslova ch umjesto $\dot{c}$, ubrzo pojavljuje i ilirski. Rješenja dalmatinskoga i ilirskog slovopisa isprepleću se u tekstu A. Torkvata Brlića (u raspravi objavljenoj u Zori dalmatinskoj 1844, v. Rišner 2015: 277) koji pak fonem $/ r /$ bilježi samo slovom $r$, dok se u ostalim člancima istoga broja "Zore dalmatinske" rabi er bez nadslovnoga znaka. 
Tako se na početku prvoga godišta "Kola", u Demetrovu Grobničkom polju, slogotvorno $/ r /$ bilježi dvoslovom èr. Nakon toga, do 1853. nalazi se àr. Tada urednikom postaje Mirko Bogović, a $/ r /$ se ponovo bilježi dvoslovom èr, no Bogović, kako sam napominje u navedenu tekstu, mijenja njegovo bilježenje u àr.

Prije Bogovićevih promjena slovopisne je promjene u "Kolo" unosio urednik Stanko Vraz 1850. godine. Te su promjene rezultat Bečkoga književnog dogovora jer prema 5. točki dogovora više nema dvoslova èr i àr. ${ }^{7}$ Druga je slovopisna razlika između Bečkog dogovora i "Kola" u bilježenju dugoga i kratkog jata. Ono je jednako kasnoj normi Zagrebačke škole: ie u dugim, je u kratkim slogovima. Prema 2. točki dogovora više nije trebalo biti mjesta za ě, ali ni za ie (samo za ije/je/e/i), no Vraz je u tome ipak zadržao hrvatsku slovopisnu tradiciju. Da je namjeravao prihvatiti neke od zaključaka Bečkoga dogovora, ali ostati pri morfonološkom načinu pisanja, potvrđuje izrijekom u Zagovoru koji donosi u "Kolu". Ondje se poziva na Bečki dogovor, za koji kaže:

U Zagrebu taj poziv nenadje velikog odziva, samo narodne novine su o toj stvari nekoliko riečih progovorile, koje se raspršiše u vietar. I pak stvar ta biaše za me od velike znamenitosti, ja obilazih naše ovdašnje spisatelje nebili ih sklonio, da mi jedan program načinimo, i da bečki predlog tražimo malo promieniti, i Vuka barem na to skloniti, da nas ostavi pri načinu koji ethimologiu neruši. Ali badava biaše moj trud, nenadjoh ni dve složne glave, a osobito gramatici nehtiedoše nikako na ništa pristati [...] (K 1850: 89).

U novinama i časopisima 19, a dijelom i 20. stoljeća, mnogo je i promjena i supostojanja u bilježenju slogotvornoga $/ r /$ i odraza dugoga jata. ${ }^{8}$ Nerijetko se u naslovnoj glavi novina čuvaju starija obilježja, dok nov način bilježenja kojega fonema ili drukčija pravopisna rješenja ulaze u same tekstove. Tako je u časopisu "Vienac", gdje se u naslovu nije mijenjalo dvoslovno bilježenje dugoga odraza jata do 1903, iako se u sam časopis ije uvodi već u godini Brozova Hrvatskoga pravopisa ${ }^{9}$ te oba načina bilježenja, dvoslovni i

\footnotetext{
Ta je točka Bečkoga dogovora jedina koja se poštuje i u čitanom "Pozoru", iako se još polovicom 19. stoljeća i ondje nalazi dvoslovno bilježenje samoglasnoga $/ r /$, i to u pismu Ivana Mažuranića uredniku (P 1885: 180).

8 Bogoslav Šulek u dodatku petnaestom broju "Nevenu" (od 20. travnja 1854.) nazvanom Književna priloga $k$ "Nevenu” objavljuje raspravu $O$ dvoglascu ie preporučujući zamijeniti ě $\mathrm{s}$ ie u dugim i je u kratkim slogovima. Donosi i rječnik Rieči sa ie i je (mjesto ě). Uredništvo pak uz Šulekov tekst piše Opazku upotrebljavajući rogato $e$ (ě).

9 Dugi je odraz jata u "Vijencu" zabilježen troslovno (kao ije) 1892, kada imenica siječanj (str.
} 
troslovni, supostoje. Dvoslovni i troslovni odraz jata potvrđuju se i u imenu časopisa "Dom i svijet/sviet" na naslovnici (Slika 1) i u zaglavlju (Slika 2) istoga, prvog broja časopisa 1919. godine:

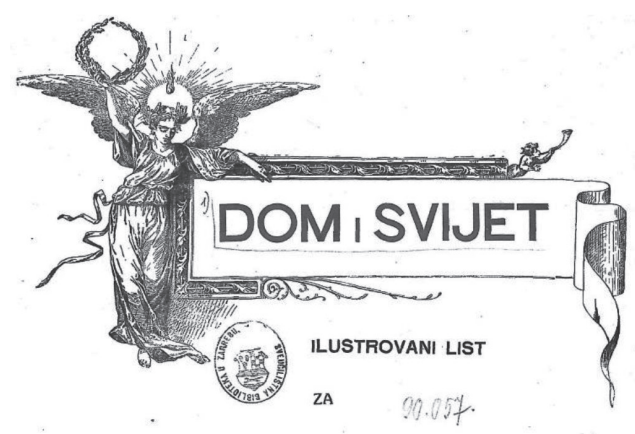

\section{ZABAVU, POUKU I VIJESTI}

DNEUNIH DOGODJAJA, JAVNOM I DRUŠTVENOM ŽIVOTU, UMJETNOSTI I ZANOSTL TRGOVINI, OBRTU, GLAZBI I KAZALIŠTU

Slika 1.

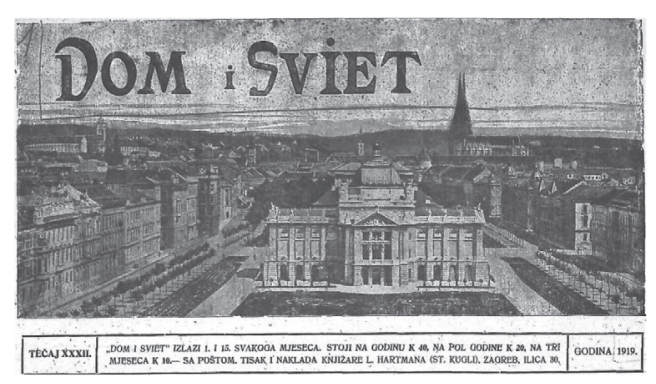

Slika 2.

Među ostvarajima se istoga fonema koji se u 19. i početkom 20. stoljeća upotrebljavaju u različitim inačicama supostojeći, a nakon toga se izmjenjujući, izdvaja se pisanje fonema $3 .{ }^{10}$ Ono je u građi druge polovice 19. stoljeća dvoslovno, s pretežitom uporabom $d j$ i rjeđom uporabom $g j$ (u tuđicama), ${ }^{11}$ iako se u manjem dijelu novina nalazi i pretežita uporaba

37) slovopisno supostoji uz siečnja u datumu 3. broja časopisa: 16. siečnja 1892.

10 O pravopisnim i slovopisnim obilježjima u 19. stoljeću opširnije u Badurina 2015: 403-429.

O jeziku hrvatskih novina i časopisa te znanstvenih tekstova u 19. stoljeću: Rišner 2015:

245-299, Horvat, Hudeček i Mihaljević 2015: 301-355.

11 Takvo je bilježenje u skladu s Mažuranićevim opisom (Mažuranić 1859 [2008]: 49). 
dvoslova gj. Riječ je o dubrovačkim tiskovinama; časopisu "Slovinac", koji je izlazio od 1878. do 1884. zastupajući sveslavenstvo, te o pravaškim novinama "Crvena Hrvatska", u kojima se gj zamjenjuje s $đ 1906$. godine. Milan Rešetar u raspravi Unifikacija našega pravopisa (Samardžija [prir.] 2001: $315^{12}$ ) potvrđuje spomenuto o pisanju fonema / $/ 3 /$ : "Ponajviše se za nj piše dj (rodjen, medju itd.), dok je Vuk predlagao gj, kao što je bilo prihvaćeno u Dubrovniku a poslije i u Bosni [...]" Slovo je đ u hrvatske novine i časopise ušlo kasno i nesustavno - u mnoge novine tek nakon dvadesetih godina 20. stoljeća ("Obzor", osječka "Hrvatska obrana" i "Hrvatski list"...), u manji dio prije ( "Iskra", "Crvena Hrvatska", vinkovačka "Svjetlost"...) ili poslije toga (splitsko "Novo doba"13). Međutim i nakon uvođenja slova $đ$ na njegovu se mjestu često nalaze dvoslovi dj i/ili gj. Zanimljivo je i da se za Banovine i Nezavisne Države Hrvatske u dijelu novina $d$ gubi te se ponovo rabi $d j$. Može se pretpostaviti da su uzrok tomu slagarske poteškoće.

\subsection{Morfološka razina}

Oblična sinonimija u novinama i časopisima 19. stoljeća posljedicom je miješanja dviju norma: norme Zagrebačke filološke škole i norme hrvatskih vukovaca. O trećem se sklonidbenom sustavu, između zagrebačkoga i vukovskoga, koji opisuje V. Pacel u Oblicima književne hrvaštine (1865), može govoriti tek u pojedinačnim primjerima zabilježenim u posljednjem riječkom godištu časopisa "Neven" 1858. godine.

Do prodora izjednačenih novoštokavskih množinskih nastavaka nakon Bečkoga dogovora dolazi u Vrazovu "Kolu", i to prijevodu pjesme Adama Mickiewicza. U većini ostalih novina i časopisa 19. stoljeća nakon Bečkoga dogovora, i usprkos njemu, prevladavaju stari nastavci Zagrebačke filološke škole. Stari i novi nastavci u većini se novinsko-časopisne građe izmjenjuju u posljednjih petnaestak godina 19. stoljeća, a osobito u posljednjem desetljeću. Njihovo supostojanje 1891. godine pokazuje "Vienac", gdje se pripovijetka Udovica Josipa Eugena Tomića objavljuje u nekoliko brojeva

12 Rasprava Milana Rešetara prvi je put objavljena u "Jugoslavenskoj njivi" 1922. godine, a ovdje se navodi prema pretisku u knjizi Jezikoslovne rasprave i članci (Samardžija [prir.] 2001: 308-316).

13 Ondje se đ redovito bilježi od "ranih tridesetih godina" (Milinović 2014: 75), iako se u rijetkim primjerima nalazi i ranije. 
starim nastavcima dativa množine; kriomice prodavao na vozove sieno $u$ Karlovac i imućnijim kmetovom. (V 1891: 306), kao i lokativa; Snieg je počeo kopniti na poljih i planinah (V 1891: 337) te instrumentala. U istom je godištu istoga časopisa i crtica Josipa Kozarca Ljudi, koji svašta trebaju, u kojoj prevladavaju novi nastavci, no još se uvijek nalazi i stari lokativ: Kuće na drvenih stupovih (V 1891: 18) te instrumental množine: granicu sječe obilježio je lugar po noći i to jedva vidljivimi znaci (V 1891: 20).

Stari se nastavci miješaju s novima i u prvom desetljeću na stranicama "Naše sloge", prvih hrvatskih novina u Istri, koje su izlazile u Trstu i Puli, kao i u časopisu "Dom i sviet", u kojem se ostataka morfološke norme Zagrebačke filološke škole rubno nalazi i potkraj drugoga desetljeća.

U 20. se stoljeće prenose i odglagolski pridjevi na -ći-glagolski prilozi sadašnji koji se sklanjaju kao participi. Oni su početkom 20. stoljeća osobito česti u reklamama za ljekovite pripravke i sredstva za uljepšavanje. Tako se 1910. godine u “Obzoru” pastile reklamiraju kao želudac jačajući proizvod, a bilježi se i sintagma boli ublažujuća sredstva (O 1910, br. 270: $1^{14}$ ) te se polovicom drugoga desetljeća 20 . stoljeća u mnogim novinama reklamira najnoviji pouzdani djelujući lijek. Početkom drugoga desetljeća 20. stoljeća nalazi se i sinonimna atributna rečenica: sredstva, koja ublažuju boli (DiS 1912, br. $22: 20$ ).

Spomenuti se odglagolski prilozi na -ći nalaze i u oglasima trgovačkih društava i osiguravajućih zavoda: Putujući činovnik traži se uz stalnu plaću $i$ povoljne uvjete (O 1913.) te u novinskim tekstovima: Ovdje za leđima borećih se četa... (O 1914, Jutarnje izdanje, br. 288: 2) U većini se novina nakon prvoga desetljeća može govoriti o sinonimiji participa $i$ atributne rečenice te postupnom prevladavanju atributne rečenice, a ostataka se spomenute uporabe nalazi i dvadesetih godina: karta, glaseća na ime glavnog urednika lista. (HL 1923.). I. Pranjković (2013: 45), govoreći o kategoriji padeža, ističe da glagolski prilog na -ći koji je poprimio obilježja pridjeva, u suvremenom jeziku15 "gubi svaku vezu s glagolom”, što pokazuje i semantika takvih oblika: ne znače privremeno, nego trajno svojstvo, kao pravi pridjevi. Osim toga takvi oblici gube obilježje nesvršenosti.

14 Uz većinu se kratica navodi godina izdanja, broj i stranica novina ili časopisa.

15 O spominjanim prilozima u suvremenom jeziku v. i Blagus Bartolec, Matas Ivanković 2014. 


\section{STILSKO PREPLETANJE - SINTAKTIČKA SINONIMIJA}

Na sintaktičkoj se razini u jeziku novina i časopisa s kraja 19. i prvih nekoliko desetljeća 20. stoljeća potvrđuju i česte nominalizacije ${ }^{16}$ te složeni glagolski predikat s infinitivom. Nominalizirani se iskazi uz nenominalizirane mogu smatrati stilskom inačicom ${ }^{17}$ jer nisu rezultat normativnih promjena. U ovom se radu izdvajaju i opisuju primjeri raščlanjivanja jednočlanog glagolskog predikata na dvočlani predikat sastavljen od suznačnoga (u navedenim primjerima pomoćnog ili modalnog) glagola i imenice.

\subsection{Raščlanjeni predikat}

U Gramatici hrvatskoga jezika za gimnazije i visoka učilišta J. Silić i I. Pranjković, dijeleći predikate prema ustrojstvu na glagolske i imenske, među imenskim predikatima opisuju raščlanjeni (dekomponirani) predikat ${ }^{18} \mathrm{kao}$ vrstu proširenoga predikata pri kojoj se "kakav samoznačni glagol raščlani na perifrazni glagol i imenicu, koja je obično glagolska i koja je često izvedena od samoznačnoga glagola" (Silić - Pranjković 2005: 292-293).

U novinama i časopisima druge polovice 19. i prve polovice 20. stoljeća među ostalim se predikatima raščlanjuje predikat misliti, i to na pomoćni glagol biti i genitiv imenice mišljenje. Takvih je primjera i u suvremenom hrvatskom jeziku, ali su izrazito stilski obilježeni. U jezikoslovnoj se literaturi ističe da se iskaz često nominalizira raščlanjivanjem predikata $u$ administrativnim i znanstvenim tekstovima kako bi se neutralizirala prije-

16 U Sintaksi hrvatskoga književnog jezika R. Katičića nominalizacija se odnosi na preobliku glagolskoga i pridjevnoga predikata u glagolsku imenicu (Katičić 1986: 476). U Hrvatskoj gramatici (Barić i sur. 1995: 579) nominalizacijom se opisuje samo preoblika glagolskoga predikata u imenicu. U tvorbi riječi nominalizacija podrazumijeva supstantivizaciju, tj. preobrazbu (konverziju); promjenu druge vrste riječi u imenicu. B. Tafra (2005: 100) o tome kaže: "Prema vrsti riječi koja nastaje naziva se i preobrazba: poimeničenje (supstantivizacija) [...]" M. Radovanović (2007: 78) pak nominalizaciju smatra “jezičnom univerzalijom” te ju opisuje kao pojavljivanje imenskih sredstava umjesto glagolskih.

17 M. Katnić-Bakaršić (2007: 250-251) dekomponirani predikat opisuje sa stilističkoga motrišta kao "sinonimičan prostom glagolskom predikatu [...]. U takvim parovima najčešće je prosti glagolski predikat neutralan, dok je dekomponirani stilski markiran”. M. Radovanović (1990: 53) nominalizaciji i raščlanjivanju predikata pristupa sintaktički, ali također ističe da je takav predikat "sinonimičan (pa i komutabilan) sa semantički ekvivalentnim jednočlanim predikatom".

18 Da se mogu raščlanjivati i glagolski oblici koji nisu predikati, navodi S. Tanasić (1995) opisujući raščlanjivanje glagolskih priloga sadašnjih i prošlih (prema: Radovanović 2007: 148). 
laznost predikacije, tj. izbjegao objekt, kao u primjerima obaviti procjenu i izdati naređenje (Pranjković 1996: 520). Primjeri iz novinsko-časopisne građe potvrđuju da se spomenuto raščlanjivanje osim u administrativnim i znanstvenim provodi i u publicističkim tekstovima. Međutim kada se jednočlani predikat misliti raščlanjuje na višečlani, i to na oblik pomoćnoga glagola biti i odglagolsku imenicu mišljenje u genitivu, s obavijesnošću je drukčije: da bi takav predikat bio dovoljno obavijestan, nužno je prenijeti dodatnu obavijest koju uz jednočlani glagolski predikat donosi objekt. Kada je predikat raščlanjen, obavijest se izriče atributnom rečenicom: $d a \boldsymbol{s u}$ Amerikanci bili mišljenja, da je rad čovjeku nedostojan (HZ 1906, br. 7: 7). Višečlani predikat s imenicom u genitivu može se upotrijebiti u rečenicama s izrečenim vršiteljem (jer su svi bili mišljenja, H 1906, br. 82: 2; Mi smo vazda bili mišljenja, JL 1915, br. 1024: 3; Nekoji su bili mišljenja, PP 1926, br. 43 : 1). Glagol se biti najčešće rabi u 3. licu množine perfekta; jer su bili mišljenja, da je u zdravom tijelu i zdrava duša (ŽL 1932, br. 8: 35), a rubno se potvrđuje i 1. lice množine. Nalazi se i 1 . lice množine te 3 . lice jednine prezenta, a u pojedinačnim primjerima 1 . lice jednine i 3. lice množine prezenta: Mišljenja smo, da njega ne će spasiti niti društvo za zaštitu životinja (LH 1923, br. 13: 2); Tko je mišljenja da treba hranu [...] poboljšati (ŽL 1934, br. 6: 40). Ostali predikati koji se raščlanjuju prema obrascu: ${ }^{19}$

jednočlani glagolski predikat $\rightarrow$ pomoćni glagol biti + odglagolska imenica $(G)$

rabe se u obezličenim rečenicama, npr. bilo je/nije bilo rasprave/ mogućnosti/sumnje:

U francezkim bolnicama je ova metoda već uvedena, pak će se u svakom slučaju, gdje bi bilo sumnje ${ }^{20}$, da je netko samo obamro, dotičnik fotografirati sa Röntgonovim zrakama ... (JL 1912, br. 36 : 1)

Ako imenici u genitivu prethodi prijedlog od (biti od koristi ${ }^{21}$ ), vršitelj se uglavnom izriče: U ostalom, to je i po vas od koristi (DiS 1900, br. 7 : 17).

19 O različitim načinima raščlanjivanja punoznačnoga predikata u suvremenom hrvatskom jeziku više u Rišner 2016: 251-258.

20 Iako je znatno češći niječni oblik perfekta ili kondicionala (nije bilo sumnje i ne bi bilo sumnje), novine i časopisi potvrđuju i nekoliko primjera jesnoga perfekta i kondicionala pomoćnog glagola biti uz genitiv imenice sumnja kao rezultat raščlanjivanja predikata sumnjati.

21 Osim imenice korist u parafrazama s pomoćnim glagolom biti i prijedlogom od mogu se upotrebljavati imenice slična značenja, ali uglavnom s atributima: biti od velikog/izuzetnog značenja/interesa/utjecaja. Usp. i primjere u crnogorskom (Šušanj 2010: 9) i srpskom jeziku (Radovanović 2007: 67-68). 
Dvočlani se predikat rabi i umjesto jednočlanoga željeti, i to na sljedeći način:

jednočlani glagolski predikat $\rightarrow$ pomoćni glagol biti + odglagolska imenica (N)

Pritom se redovito izriču podatci o vršitelju, i to: 1 . pridjevom ili zamjenicom sročnim s imenicom želja - u nominativu, 2. imenicom ili ličnom zamjenicom u dativu i 3. imenicom, ličnom/posvojnom zamjenicom ili pridjevom u genitivu:

Moja je želja, da me pošaljete u moju otačbinu. (DiS 1907, br. 16: 315); Ista želja nam je svim uviek bila (NN 1868, br. 231: 1); Želja je pak Engleza (NN 1849, br. 158: 532)

Drugi je način raščlanjivanja glagola željeti, prema obrascu:

jednočlani glagolski predikat $\rightarrow$ nepunoznačni glagol imati + odglagolska imenica (A)

zabilježen tek sporadično, dok se u suvremenom hrvatskom jeziku javlja češće.

\subsection{Infinitiv u složenom glagolskom predikatu uz pomoćne i modalne glagole}

Novine i časopisi s kraja 19. i početka 20. stoljeća potvrđuju i složene glagolske predikate u kojima se kao predikatna riječ pojavljuje infinitiv glagola uz pomoćni glagol biti, i to u bezličnim rečenicama s modalnim značenjem. Da je 3. lice prezenta pomoćnog glagola biti u takvim rečenicama bilo često, u građi potvrđuju predikati bojati se je i diviti se je:

Ako se puste činovnici u skupštinu, bojati se je... (NP 1869, br. 399: 1586); Bojati se je, da mladi neiskusni učitelj [...] neće polučiti Bogzna kakvog uspjeha (NS 1910, br. 42 :1); Bojati se je, da će se i ova pobuda bečkoga dvora [...] morati slomiti o krutoj zbilji realnoga života (JL 1913, br. 421: 3).

Uporaba infinitiva uz glagol biti bila je uobičajena, što potvrđuje opis M. Divkovića s kraja 19. stoljeća (1899: 103-104) u Hrvatskoj sintaksi za školu: "Glagol jesam, biti s infinitivom pokazuje, da se radnja mora ili može vršiti, a niječno, da radnja nije moguća." U niječnim pak rečenicama na mjestu glagola biti uglavnom je trebati, a u jesnim bezličnim rečenicama $u$ drugoj polovici 19. i prvom dijelu 20. stoljeća prevladava uporaba infinitiva s prezentom pomoćnoga glagola biti umjesto prezenta modalnoga trebati. 
Usprkos različitoj čestotnosti može se govoriti o supostojanju obaju predikata:

Bojati se je samo toga, da ta ruka posegne [...] (Z 1869, br. 75: 3) / bojati se treba svakojakih nemirah (Z 1869, br. 11: 1)

Glagoli biti i trebati uz infinitiv u uspoređenoj su građi značenjski izjednačeni; oba imaju modalno značenje mogućnosti i nužnosti. ${ }^{22} \mathrm{U}$ sintaktički se sinonimnom obezličenom predikatu na njihovu mjestu mogu naći i moći (Tu i tamo čitati je u izvješćima, O 1914, Jutarnje izdanje, br. 288: 2 / Gotovo svaki dan može se čitati u novinama, JL 1913, br. 349: 6) te imati: Naročito se ima zahvaliti nastojanju ovih nadzornika, da palež danas spada u ona zločinstva... (DiS 1899, br. 15: 311). Obezličeni glagol imati i infinitiv kao njegova leksička dopuna nalaze se u natječajima i zakonima koji se objavljuju $\mathrm{u}$ novinama te $\mathrm{u}$ tekstovima koji raspravljaju o administrativnim pitanjima:

Ima se protiv ovih osoba kazneni postupak provesti. (O 1914, br. 288: 2)

Paušalna svota rasvjete ima se povisiti za 50 posto. (Vt 1920, br. 50: 3)

Značenje je takvih infinitiva uz glagol imati zapovjedno, a predstavljaju obilježje administrativnoga stila.

Viši se stupanj nužnosti izriče predikatom u kojem uz infinitiv ne stoji trebati nego drugi modalni glagol morati potvrđujući sintaktički sinonimno ustrojstvo bliskoga, ali ne posve jednakoga značenja. Predikati s glagolom morati i infinitivom u novinsko-časopisnoj građi druge polovice 19. i početka 20. stoljeća češći su nego oni s trebati, ali se razlikuju s obzirom na vršitelja: dok se glagol trebati (kao i biti) uz infinitiv rabi i u bezličnim rečenicama, morati se uz infinitiv nalazi u rečenicama s konkretnim vršiteljem (koji je poznat i kada u surečenici s infinitivom nije izrečen):

[...] treba se diviti redu i točnosti (O 1914, Jutarnje izdanje, br. 288: 2); Umjetničkoj izradbi i tehničkoj izvedbi diviti se je. (Vt 1911, br. 11: 2); Bojati se je, da ne bukne generalni štrajk. (JL 1912, br. 137: 6)

Ako danas trgovac stoji pred propalošću, odnosno stečajem, a mora se bojati da će radi razsipavanja robe [...] biti osudjen kao propalica [...] (DiS 1899, br. 15:311)

Iako su složeni glagolski predikati s infinitivom češći u bezličnim rečenicama u kojima je vršitelj skupni, nekonkretiziran, novinsko-časopisna

22 R. Katičić (1986: 476) o uporabi infinitiva u spomenutom značenju kaže: "Infinitivi, sa sponom ili bez nje, javljaju se kao predikatne riječi u značenju nužde, mogućnosti ili predodžbe [...]" navodeći primjere iz književnoumjetničkoga stila od 18. do 20. stoljeća. 
građa druge polovice 19. i početka 20. stoljeća potvrđuje i primjere izricanja vršitelja dativom, uglavnom lične zamjenice: Još nam je napokon spomenuti (NP 1867, br. 1: 1), Iztaknuti nam je još, da je jelo i piće prve vrsti. (JL 1913, br. 50: 3).

\section{I NORMATIVNA I STILSKA SUPOSTOJANJA - PRIJEDLOŽNI IZRAZI I GRAMATIKALIZIRANI INSTRUMENTALI IMENICA}

U tekstu Sintaktičke inovacije u hrvatskome standardnom jeziku (19451995) I. Pranjković (2001: 96-104) kao jedno od obilježja znanstvenog i administrativnog stila navodi prijedložne izraze na osnovi i na temelju $+\mathrm{G}^{23}$ kojima se izriče uzrok kriterija. Ističe da su takvi izrazi, kao i poprijedloženi instrumentali za izricanje uzroka povoda, češći u novije vrijeme. Međutim starija građa uspoređena u ovom radu svjedoči o čestoj uporabi prijedložnih izraza uzročnoga značenja te se spomenuta tvrdnja može dopuniti vraćanjem na novinsko-časopisne početke: u publicistički stil već u drugoj polovici 19. stoljeća ulaze mnogi ustaljeni prijedložni izrazi, i to često pod utjecajem administrativnoga stila kojim su pisani zakoni i natječaji objavljivani na stranicama novina i časopisa. Takvi se prijedložni izrazi rabe umjesto jednoga prijedloga osobito pri izricanju uzroka ${ }^{24}$ i namjere; prijedložnu ulogu pri izricanju uzroka kriterija od početaka hrvatskih novina imali su izrazi koje spominje I. Pranjković i u suvremenom hrvatskom jeziku: na osnovi i, češće, na temelju. Frazeologizirani prijedložni izrazi česti su i pri izricanju namjere; od druge polovice 19. stoljeća do sedamdesetih godina 20. stoljeća tomu služe izrazi $u$ cilju i, češće, $u s v r h u^{25} \mathrm{~s}$ imenskom riječju u genitivu.

Poprijedloženi instrumentali imenica, koje I. Pranjković (1996: 523) s pravom vezuje uz publicistički stil, također se nalaze u novinama od njihovih početaka: često su vremenskoga značenja (tečajem, tokom i tijekom;

23 O tome i: Pranjković 1996: 522, Silić i Pranjković 2005: 379.

24 Prijedlog se zbog u novinama i časopisima 19. i prve polovice upotrebljavao manje nego danas, a umjesto njega rabili su se uslijed te nerijetko radi, što potvrđuje pretapanje semantičkih polja uzroka i namjere, koje se dijelom nastavlja i u drugoj polovici 20. stoljeća, do kraja šezdesetih i početka sedamdesetih godina 20. stoljeća.

25 J. Silić i I. Pranjković (2005: 379) kao obilježje administrativno-poslovnog stila koje potvrđuje eksplicitan (potpuno iskazan) način izražavanja opisuju uporabu izraza s namjerom, sa svrhom i s ciljem uz (najčešće) glagolsku imenicu, i to "umjesto prijedloga radi i namjerne rečenice" u suvremenom hrvatskom jeziku. 
početkom; krajem, koncem...), ${ }^{26}$ a izriču i prigodnu temporalnost: povodom $\mathrm{i}$, češće, prigodom, te način i sredstvo (putem, posredstvom). Savjeti štokavskih purista početkom dvadesetoga stoljeća redovito su protiv uporabe poprijedloženih instrumentala, osobito u vremenskom ${ }^{27} \mathrm{i}$ značenju prigodne temporalnosti, što dijelom utječe na uporabu sinonimnih izraza: i Rožić (1913: 89) i Maretić (1924: 109) umjesto prigodom + G preporučuju $o+$ lokativ, a umjesto povodom Maretić predlaže $u$ povodu. Suprotno savjetima štokavskih purista, u novinama i časopisima češće se rabe sekundarni prijedlozi, tj. poprijedloženi instrumentali.

\section{ZAKLJUČAK}

Iako je u ovom radu iznesen tek djelić istraživanja novinsko-časopisne građe, i on potvrđuje početnu misao Ive Pranjkovića: inačice su jezična stvarnost, ali i nužnost, kako u vrijeme prijelaza iz jedne norme u drugu, tako i pri funkcionalno-stilskom raslojavanju. U novinama i časopisima 19. i 20. stoljeća potvrđuju se mnoge promjene, osobito slovopisne, primjerice $u$ bilježenju slogotvornoga $/ r /$ i odraza dugoga jata, ali i drugih fonema. Može se govoriti i o sintaktičkoj sinonimiji između nominaliziranih i nenominaliziranih ustrojstava koja se potvrđuje pri raščlanjivanju glagolskog predikata. U građi se nalazi više vrsta raščlanjivanja, a u radu se izdvajaju primjeri u kojima višečlani predikat čine pomoćni glagol biti i odglagolska imenica u nominativu ili genitivu (misliti $\rightarrow$ biti mišljenja; željeti $\rightarrow$ biti želja $($ komu)). Supostojanje potvrđuju i složeni glagolski predikati s infinitivom kao predikatnom riječju uz pomoćni glagol biti ili trebati u bezličnim rečenicama s modalnim značenjem, kao i prijedložni izrazi, sekundarni prijedlozi i pravi prijedlozi u prijedložnoj ulozi.

26 Svi instrumentali koji se rabe kao sekundarni prijedlozi opisuju se u: Glušac, Rišner 2016.

27 I. Broz (2000: 75-77), T. Maretić (1924) i V. Rožić (1913) pišu protiv vremenskoga instrumentala u izrazu početkom mjeseca, a Rožić (1913: 116-117) i Maretić (1924: 153, 154) nepravilnima opisuju i uporabu poprijedloženoga instrumentala tečajem. 


\section{NAVEDENI IZVORI ${ }^{28}$ I KRATICE IZVORA:}

(DiS) “Dom i sviet”. Zagreb. 1892, 1899, 1900, 1912.

(H) - "Hrvat". Gospić. 1906.

(HL) - "Hrvatski list". Osijek. 1923.

(HZ) - "Hrvatska zastava". Chicago.1906.

(JL) - "Jutarnji list". Zagreb. 1912, 1913, 1915.

(K) - "Kolo" 1842.-1853. Pretisak 1993. [Ur. M. Kuzmanović, S. Lipovčan, M. Mirić i A. Stamać.] Rariteti: pretisci, 1. Zagreb: Erasmus naklada.

(LH) - "Lički Hrvat". Gospić. 1923.

(NN) - "Narodne novine". Zagreb. 1849, 1868.

(NP) - "Novi Pozor". Beč. 1867, 1869.

(NS) - "Naša sloga". Pula. 1910.

(O) - "Obzor". Zagreb. 1910, 1914. (Jutarnje izdanje)

(PP) - "Pučki prijatelj". Trst. 1926.

(V) - "Vienac". Zagreb. 1891.

(Vt) - "Virovitičan". Virovitica. 1920.

(Z) - "Zatočnik". Sisak. 1869.

(ŽL) - “Ženski list”. Zagreb. 1932, 1934.

\section{LITERATURA}

Badurina, Lada. 2015. Hrvatski slovopis i pravopis u 19. stoljeću. Povijest hrvatskoga jezika, 4. knjiga: 19. stoljeće. [ur. Josip Lisac, Ivo Pranjković i Marko Samardžija], Zagreb: Društvo za promicanje hrvatske kulture i znanosti Croatica, 403-429.

Barac, Antun. 1936. Sto godina novije hrvatske književnosti i “Obzor”. Obzor. Spomen knjiga 1860-1935, Zagreb: Tipografija d.d. Zagreb. 254-260.

Barić, Eugenija i sur. 1995. Hrvatska gramatika. Zagreb: Školska knjiga.

Blagus Bartolec, Goranka i Ivana Matas Ivanković. 2014. Odglagolski pridjevi na -ći u suvremenome hrvatskom jeziku. Riječki filološki dani 9: Zbornik radova s Međunarodnoga znanstvenog skupa Riječki filološki dani održanoga 22. do 24. studenoga 2012. [ur. Diana Stolac], Rijeka: Filozofski fakultet, 521-531.

Broz, Ivan. 2000. Filološke sitnice i pabirci. Prikupio i pogovor napisao Marko Samardžija. Zagreb: Pergamena d. o. o.

Divković, Mirko. ${ }^{2}$ 1889. Hrvatska sintaksa za školu. Zagreb: Tisak Dioničke tiskare.

28 Svi su izvori osim "Vijenca"i "Hrvatskog lista" digitalizirani i dostupni na portalu Stare hrvatske novine i časopisi; http://dnc.nsk.hr/ (pristupljeno 10. siječnja 2018.). 
Glušac, Maja i Vlasta Rišner. 2016. O uporabi i značenju sekundarnih prijedloga nastalih gramatikalizacijom imenica. "Rasprave: Časopis Instituta za hrvatski jezik i jezikoslovlje" 42, 2, 229-260.

Horvat, Marijana, Lana Hudeček i Milica Mihaljević. 2015. Jezik hrvatskih znanstvenih tekstova u 19. stoljeću. Povijest hrvatskoga jezika, 4. knjiga: 19. stoljeće. [ur. Josip Lisac, Ivo Pranjković i Marko Samardžija], 301-355. Zagreb: Društvo za promicanje hrvatske kulture i znanosti Croatica, 245-299.

Katičić, Radoslav. 1986. Sintaksa hrvatskoga književnog jezika, Nacrt za gramatiku. Zagreb: JAZU, Globus.

Katnić-Bakaršić, Marina. ${ }^{2} 2007$. Stilistika. Sarajevo: Naučna i univerzitetska knjiga.

Maretić, Tomo. 1924. Hrvatski ili srpski jezični savjetnik za sve one koji žele dobro govoriti i pisati književnim našim jezikom, Dopuna Broz-Ivekovićevu "Rječniku hrvatskoga jezika". Zagreb: JAZU.

Mažuranić, Antun. 1859. Slovnica Hèrvatska za gimnazije i realne škole. Pretisak Instituta za hrvatski jezik i jezikoslovlje. Zagreb. 2008.

Milinović, Anđela. 2014. Jezik i pravopis splitskoga novinstva između dvaju svjetskih ratova. Doktorski rad. Zagreb: Filozofski fakultet Sveučilišta u Zagrebu.

Pranjković, Ivo. 1996. Funkcionalni stilovi i sintaksa. "Suvremena lingvistika", 41-42, 519-527.

Pranjković, Ivo. 2001. Druga hrvatska skladnja: sintaktičke rasprave. Zagreb: Hrvatska sveučilišna naklada.

Pranjković, Ivo. 2010. Ogledi o jezičnoj pravilnosti. Zagreb: Disput.

Pranjković, Ivo. 2013. Gramatička značenja. Zagreb: Matica hrvatska.

Radovanović, Milorad. 1990. Spisi iz sintakse i semantike. Novi Sad: Dobra vest.

Radovanović, Milorad. 2007. Stari i novi spisi. Ogledi o jeziku i umu. Sremski Karlovci - Novi Sad: Izdavačka knjižarnica Zorana Stojanovića.

Rišner, Vlasta. 2015. Jezik hrvatskih novina i časopisa u 19. stoljeću. Povijest hrvatskoga jezika, 4. knjiga: 19. stoljeće. [ur. Josip Lisac, Ivo Pranjković i Marko Samardžija], Zagreb: Društvo za promicanje hrvatske kulture i znanosti Croatica, 245-299.

Rišner, Vlasta. 2016. Jezik medija kao s(t)jecište različitih stilova. Jezik medija nekada i sada: Zbornik radova sa znanstvenoga skupa održanoga 6. i 7. lipnja 2014. [ur. Vlasta Rišner], Zagreb - Osijek: Hrvatska sveučilišna naklada - Filozofski fakultet, 236-262.

Rožić, Vatroslav. 1913. Barbarizmi u hrvatskom jeziku, Zagreb: Tisak i naklada knjižare L. Hartmana.

Samardžija, Marko. 1993a. Hrvatski jezik u Nezavisnoj Državi Hrvatskoj. Zagreb: Hrvatska sveučilišna naklada.

Samardžija, Marko. 1993b. Jezični purizam u NDH: jezični savjeti Hrvatskoga državnog ureda za jezik. Prikupio i za tisak priredio Marko Samardžija. Zagreb: Hrvatska sveučilišna naklada. 
Samardžija, Marko [prir.]. 2001. Jezikoslovne rasprave i članci. Franjo Iveković, Ivan Broz, Tomo Maretić, Vatroslav Rožić, Milan Rešetar, Antun Radić, Nikola Andrić, Dragutin Boranić. Stoljeća hrvatske književnosti. Zagreb: Matica hrvatska.

Samardžija, Marko. 2012. Hrvatski jezik i pravopis: od ujedinjenja do kraja Banovine Hrvatske (1918.-1941.). Zagreb: Školska knjiga.

Silić, Josip i Ivo Pranjković. 2005. Gramatika hrvatskoga jezika za gimnazije i visoka učilišta. Zagreb: Školska knjiga.

Šušanj, Jelena. 2010. Dekomponovanje leksema i birokratizacija jezika na primjerima iz crnogorskih dnevnih novina. "Lingua Montenegrina", III, 5, 3-46.

Tafra, Branka. 2005. Od riječi do rječnika. Zagreb: Školska knjiga.

\section{SUMMARY}

\section{ON NORMATIVE AND STYLISTIC PARALLEL FORMS OF THE STANDARD LANGUAGE IN THE NEWSPAPERS AND PERIODICALS OF THE $19^{\mathrm{TH}}$ AND THE FIRST HALF OF THE $20^{\mathrm{TH}}$ CENTURIES}

The article discusses the existence of parallel forms in various spelling, morphological and syntactic characteristics of Croatian newspapers and periodicals from the $19^{\text {th }}$ and the first half of the $20^{\text {th }}$ centuries (until the mid-1940). Special attention is paid to the realization of the vocalic $/ r /$ and of the phoneme $/ \xi /$, to the reflex of the long yat, to old-štokavian and new-štokavian endings for the plurals of the dative, locative and instrumental cases and to the use of present participles as attributes. The analysis has shown that a larger part of the newspaper and magazine corpus records no fast and thorough normative changes on any of the compared levels. In addition to normative variants, the analysis has also included stylistic variants on the syntactic level (nominalised/non-nominalised expressions). The analysis has also included the decomposition of a one-verb predicate into a two-word predicate consisting of a semisemantic verb (the analysed examples contain auxiliary or modal verbs) and a noun, as well as complex verbal predicates consisting of infinitives followed by the auxiliary verb biti (be) in impersonal clauses with modal meaning.

Key words: newspapers and magazines of the $19^{\text {th }}$ and the first half of the $20^{\text {th }}$ centuries, parallel forms, nominalisation, decomposition of the predicate, infinitive, syntactic synonymy 